\title{
Role of Bacterial Exopolymers and Host Factors on Adherence and Phagocytosis of Staphylococcus aureus in Foreign Body Infection
}

\author{
Flisabetta Falcieri,* Pierre Vaudaux, Elzbieta Huggler, \\ Daniel Lew, and Francis Waldvogel
}

\author{
From the Department of Morphology, University Medical \\ Center, and the Division of Infectious Diseases, Department \\ of Medicine, University Hospital, Geneva, Switzerland
}

\begin{abstract}
Using a previously developed guinea pig model of foreign body infection, we examined ultrastructural and functional surface alterations of Staphylococcus aureus strain Wood 46 during the early phase of infection. Exopolymer-free bacteria were prepared and inoculated into subcutaneously implanted tissue cages. After three hours, the bacteria showed abundant capsular and intercellular exopolymers, which were visualized by transmission electron microscopy. Exopolymers were also produced by $S$. aureus exposed in vitro to fluid from the tissue cage. In contrast, human serum albumin prevented exopolymer production by $S$. aureus. The influence of exopolymers on the susceptibility of $S$. aureus to ingestion and phagocytic killing by neutrophils was tested in vitro and found to be negligible. Furthermore, adherence of $S$. aureus to fibronectin-coated surfaces was unaffected by the presence or absence of exopolymers. Thus, in our experimental model, exopolymers are produced early during the onset of infection, but they have little impact on adherence and phagocytosis.
\end{abstract}

Clinical foreign body infections are characterized by their limited spread beyond the tissues in immediate contact with the implants, their poor response to antibiotic treatment, and their spontaneous cure after removal of the prosthesis $[1,2]$. Correlating with these clinical observations, animal models of foreign body infections (primarily with staphylococci) have demonstrated the high infective power of a low inoculum and confirmed the ineffectiveness of local host defense mechanisms against microorganisms colonizing the implants [3-5].

In addition to ineffective host defense mechanisms, other factors may explain the high susceptibility of foreign bodies to bacterial infections. Several reports [6-13] have described the production of bacterial biofilms on the surface of implanted biomaterials. Scanning and transmission electron microscopy showed these biofilms to be composed of extensive bacterial microcolonies embedded in a highly hydrated, fibrous matrix made of either pure polysaccharide or glycoproteins [11]. The biofilms

Received for publication $11 \mathrm{June}$ 1986, and in revised form 29 August 1986.

This work was supported by grants $3.990-0.84$ and 3.460 .83 from the Swiss National Research Foundation.

Please address requests for reprints to Dr. Pierre Vaudaux, Division of Infectious Diseases, Department of Medicine, University Hospital, CH-1211 Geneva 4, Switzerland.

* Present address: Instituto di Anatomia Umana Normale, Università di Bologna, Bologna, Italy. probably promote bacterial adherence to the foreign surfaces [6-13] and reduce the susceptibility of embedded microorganisms to host clearance mechanisms and to treatment with antibiotics [6-15]. Various terms have been used to designate the bacteriaproduced biofilm: slime [6-9], glycocalyx [10-13], exopolysaccharide [16], or more simply, extracellular polymeric substances (EPS) [17].

The presence of host-derived adhesins contributing to the colonization of biomaterials by microorganisms has also been described recently. Various blood- or tissue-derived proteins or glycoproteins, such as fibrinogen [18], laninin [19], or fibronectin [20-22], may interact with $S$. aureus. We have recently shown [23] that fibronectin was deposited on biomaterials implanted subcutaneously into guinea pigs and contributed significantly to increased staphylococcal adherence. The characteristics of fibronectin adsorption onto polymethylmethacrylate and the promotion of $S$. aureus adherence were also studied in detail in a simplified in vitro system [24].

In this study we use a recently developed experimental model of foreign body infection to analyze the sequence of morphological changes occurring on the surface of staphylococci. Using a specifically designed procedure for injecting exopolymer-free bacteria into tissue cages implanted subcutaneously in guinea pigs, we monitored the production of staphylococcal exopolymers within the first $3 \mathrm{hr}$ of experimental foreign body infection. With 
simplified in vitro assay conditions, we also studied the role of exopolymers in the adherence properties of staphylococci and the susceptibility of staphylococci to phagocytosis by neutrophils.

\section{Materials and Methods}

Bacterial strains. We used Staphylococcus aureus strain Wood 46, which lacks protein A [25], throughout this study. A total of $10^{8} \mathrm{cfu}$ from an overnight culture was incubated in $50 \mathrm{ml}$ of Mueller-Hinton broth for $3 \mathrm{hr}$ at $37 \mathrm{C}$, grown to a total amount of $5 \times 10^{9} \mathrm{cfu}$, washed by two centrifugations at $3,000 \mathrm{~g}$ for $10 \mathrm{~min}$, and suspended at a final concentration of $10^{\circ} \mathrm{cfu} / \mathrm{ml}$.

Animal model. Tissue cages made of polymethylmethacrylate were implanted subcutaneously into guinea pigs as described previously [4]. After four weeks, samples of sterile fluid from the tissue cage (TCF) were obtained by percutaneous aspiration [4].

EPS. The EPS were removed from the washed 3-hr culture of $S$. aureus Wood 46 by ultrasonic treatment for $10 \mathrm{sec}$ at $40 \mathrm{~W}$ with a B 12 Sonifier ${ }^{\circledR}($ Branson, Danbury, Conn); the removal of EPS was confirmed by electron microscopy (see below). After sedimentation for $10 \mathrm{~min}$ at $3,000 \mathrm{~g}$, the EPS-free bacterial cells were suspended in PBS (GIBCO, Paisley, Scotland) at a concentration of $10^{8} \mathrm{cfu} / \mathrm{ml}$. The EPS fragments present in the supernatant after the low-speed centrifugation were sedimented by overnight ultracentrifugation at $150,000 \mathrm{~g}$. The EPS-f ree bacteria were then injected into tissue cages at a concentration of $10^{8} \mathrm{cfu} / \mathrm{ml}$. This high inoculum was selected to facilitate study of the bacterial cells by electron microscopy. Samples of TCF were obtained after either 1, 2, or $3 \mathrm{hr}$ of infection, and the cells contained in the sample (including leukocytes and bacteria) were prepared for electron microscopy (see below). When EPS-free bacteria were studied for EPS production in vitro, they were incubated for 1-3 $\mathrm{hr}$ at $37 \mathrm{C}$ in test tubes containing $1 \mathrm{ml}$ of PBS supplemented with either $20 \%$ TCF, $10 \%$ guinea pig serum, or $5 \mathrm{mg}$ of human serum albumin $/ \mathrm{ml}$ and prepared for electron microscopy.

Light microscopy. Capsular exopolymers were visualized by the India ink test, as previously described [26].

Transmission electron microscopy. After incubation under conditions affecting the production of EPS, the $10^{9}$-cfu portions of $S$. aureus were thor- oughly washed to remove the protein-containing media, fixed for $1 \mathrm{hr}$ at $4 \mathrm{C}$ with $2.5 \%$ glutaraldehyde in $0.1 \mathrm{M}$ phosphate buffer, rinsed, and postfixed with $2 \% \mathrm{OsO}_{4}$ in Millonig phosphate buffer for $1 \mathrm{hr}$. After a quick passage through $50 \%$ alcohol, the bacteria were contrasted by using $2 \%$ uranyl acetate in $50 \%$ alcohol for $30 \mathrm{~min}$ in the dark. Specimens were dehydrated with graded alcohols and embedded in Epon. Thin sections were collected on parlodion carbon-coated copper grids and stained with uranyl acetate and lead citrate [27].

Preparation of neutrophils. Acute peritoneal exudates rich in PMNLs ( $>95 \%$ neutrophils) were obtained from guinea pigs after two intraperitoneal injections of sterile glycogen, as previously described [4].

Uptake of radiolabeled bacteria by neutrophils. We used bacterial cells that expressed a constant amount of EPS to evaluate the specific contribution of EPS to bacterial uptake by neutrophils. The 3-hr culture of $S$. aureus Wood 46 in Mueller-Hinton broth was radiolabeled with $\left[{ }^{3} \mathrm{H}\right]$ thymidine as previously described [23, 24]. The cells were washed and sonicated as described above. One $10^{8}$-cfu portion of the culture was immediately fixed for $18 \mathrm{hr}$ with $0.5 \%$ formaldehyde at $4 \mathrm{C}$, and the other portion was grown for another $2 \mathrm{hr}$ at $37 \mathrm{C}$ in PBS supplemented with $20 \%$ TCF to allow further production of EPS before fixation in cold formaldehyde. After fixation, EPS-free or EPS-rich bacteria were rinsed and suspended in PBS. For the uptake assay, $10^{6}$ neutrophils in a final volume of $1 \mathrm{ml}$ were mixed in a shaking water bath with $4 \times 10^{6} \mathrm{cfu}$ equivalents of fixed bacteria (either EPS-free or EPS-rich) that had been preopsonized for $15 \mathrm{~min}$ with either $0.1 \mathrm{ml}$ of pooled guinea pig serum or $0.2 \mathrm{ml}$ of pooled TCF. We removed $0.1-\mathrm{ml}$ portions of the phagocytic mixture at 0,15 , and $30 \mathrm{~min}$ to evaluate bacterial uptake by neutrophils. Uningested bacteria were removed by selective lysis in a solution containing lysostaphin (20 units/ml; Sigma, St. Louis) and pancreatic DNase I ( $20 \mu \mathrm{g} / \mathrm{ml}$; Sigma). Each 0.1 -ml portion of the phagocytic mixture was incubated with $0.9 \mathrm{ml}$ of the lysostaphin-DNase solution in PBS (supplemented with $1 \mathrm{mM} \mathrm{MgSO}_{4}$ ) for $20 \mathrm{~min}$ at 37 $C$ with occasional shaking. Previous work $[28,29]$ has demonstrated that $S$. aureus ingested by neutrophils are fully protected from lysostaphin-induced lysis. After the extracellular bacteria were digested by the lysostaphin-DNase solution, neutrophils containing ingested bacteria were sedimented at $300 \mathrm{~g}$ 
for $5 \mathrm{~min}$ and washed in PBS. The neutrophils were suspended in $1 \mathrm{ml}$ of PBS supplemented with $1 \mathrm{mM}$ $\mathrm{MgSO}_{4}, 0.1 \%$ Triton X-100, lysostaphin (20 units/ $\mathrm{ml})$, and DNase $(20 \mu \mathrm{g} / \mathrm{ml})$ and digested for $20 \mathrm{~min}$ at $37 \mathrm{C}$. We then added $1 \mathrm{mg}$ of $3 \times$ crystallized trypsin (Serva Feinbiochemica, Heidelberg, Germany) $/ \mathrm{ml}$ to the solution to allow complete recovery of the radioactivity associated with the ingested bacteria. The radioactivity was estimated by using a liquid scintillation counter (Beckman Instruments, Fullerton, Calif).

Adherence of S. aureus to fibronectin-coated coverslips. Using previously described techniques [23, 24], we coated polymethylmethacrylate coverslips with purified fibronectin by incubating them for 1 $\mathrm{hr}$ at $37 \mathrm{C}$ in PBS containing $40 \mu \mathrm{g}$ of fibronectin $/ \mathrm{ml}$.
Radiolabeled bacteria $[23,24]$ were incubated under conditions affecting EPS production by one of the foilowing procedures. (I) A portion of sonicated bacteria was grown for $2 \mathrm{hr}$ at $37 \mathrm{C}$ in PBS supplemented with either $20 \%$ TCF, $10 \%$ guinea pig se$\mathrm{rum}$, or $5 \mathrm{mg}$ of human serum albumin $/ \mathrm{ml}$; rinsed; and suspended in PBS. After adjusting the cell concentration to $4 \times 10^{6} \mathrm{cfu}$ for each incubation mixture, we tested viable bacteria for adherence to fibronectin-coated coverslips as described previously [24]. (2) Another portion of sonicated bacteria was also grown for $2 \mathrm{hr}$ as described under the first procedure, but the bacteria were fixed for $18 \mathrm{hr}$ with $0.5 \%$ formaldehyde at $4 \mathrm{C}$, rinsed, and tested in the adherence assay with fibronectin-coated coverslips. (3) A third portion of sonicated bacteria was immedi-
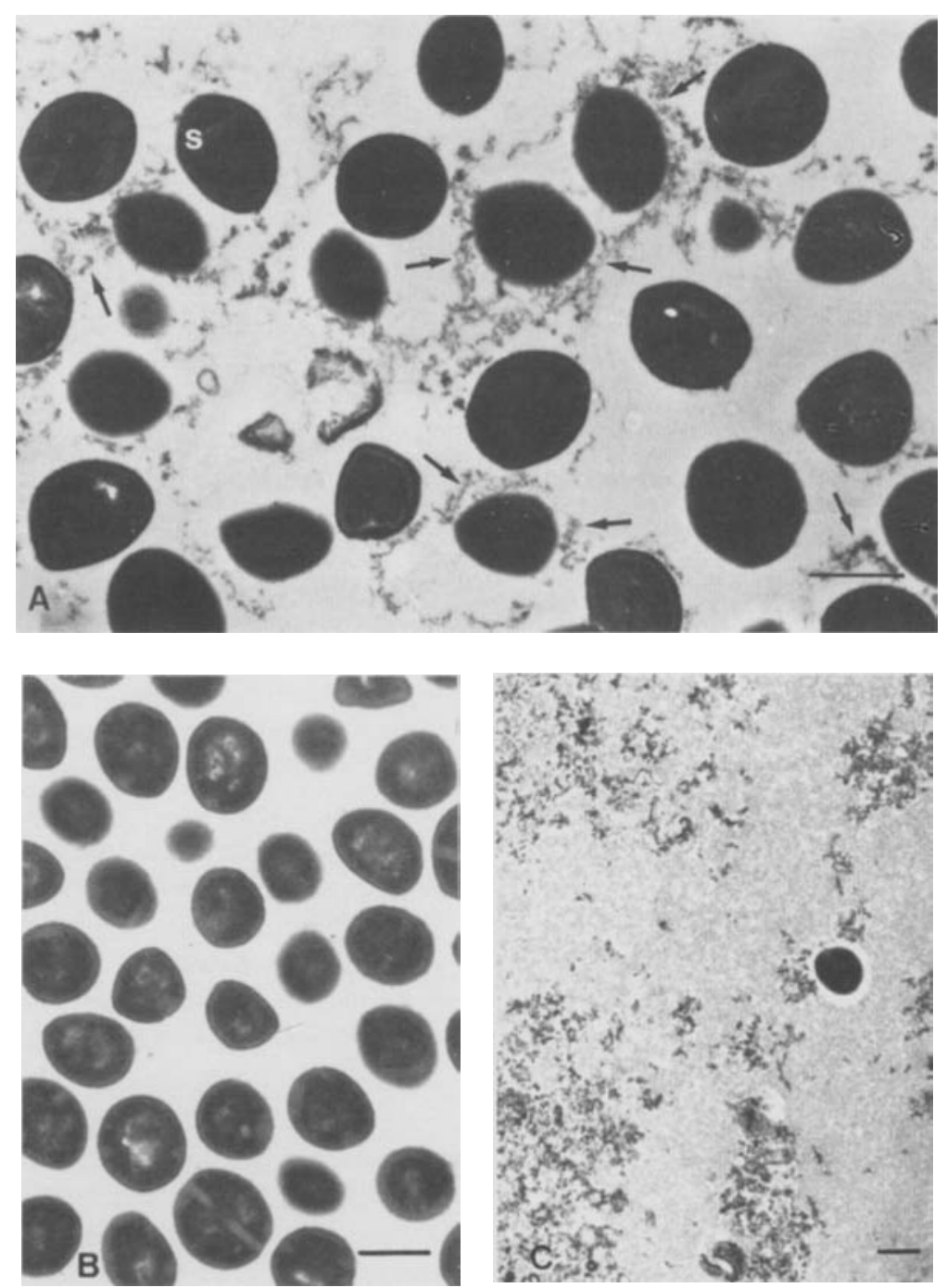

Figure 1. (A) Untreated control bacteria of $S$. aureus Wood 46 grown in Mueller-Hinton broth showing septa $(s)$ in dividing forms and EPS (arrows) around the cells and in the intercellular spaces. (B) EPS-free $S$. aureus Wood 46 observed after the sonication treatment seem to be completely deprived of EPS. (C) Concentration of the stripped-off EPS by ultracentrifugation, with one contaminating bacterial cell. Bars $=0.5 \mu \mathrm{m}$. 
ately fixed under EPS-free conditions for $18 \mathrm{hr}$ with cold formaldehyde, rinsed, and incubated for a further $2 \mathrm{hr}$ at $37 \mathrm{C}$ in PBS supplemented with either $20 \% \mathrm{TCF}, 10 \%$ guinea pig serum, or $5 \mathrm{mg}$ of human serum albumin $/ \mathrm{ml}$; this incubation was followed by rinsing in PBS. The adherence assays used $4 \times 10^{6} \mathrm{cfu}$ equivalents (as measured by radioactivity counts) with fibronectin-coated coverslips.

\section{Results}

Morphologic observations. We examined thin sections of bacterial cells from a 3-hr culture grown in a conventional broth medium (Mueller-Hinton broth) and found finely dispersed EPS either attached to the bacterial cell wall or located in the intercellular spaces.
To study EPS production by bacterial cells during the onset of experimental foreign body infection, we inoculated EPS-free bacteria into the TCF. Accordingly, the 3-hr culture of $S$. aureus Wood 46 was treated by sonication (as indicated above) to produce EPS-free bacterial cells (figure 1, A). The EPS separated from $S$. aureus by sonication and subsequent low-speed centrifugation could be recovered as a pellet after high-speed centrifugation, and we observed the EPS by transmission electron microscopy (figure 1, C). The EPS fragments stripped from $S$. aureus by sonication and reincubated with EPS-free bacteria before the high-speed centrifugation did not reassociate with the bacterial cells (data not shown).

Under in vivo conditions of experimental foreign body infection, EPS were rapidly produced by $S$. aureus Wood 46 (figure 2 ). One hour (figure $2, \mathrm{~A}$ ) or
Figure 2. (A) Neutrophilic granulocyte found in the infected TC:F 1 hr after inoculation of the EPS-free bacteria; ingested bacterial cells are surrounded by abundant electron-dense EPS (arrows) in the cytoplasmic vacuoles $(v)$; cells are surrounded by abundant electron-dense F.PS (arrows) $n=$ neutrophil nucleus. (B) A bundant EPS (arrows) in bacterial cells ingested by a phagocyte $3 \mathrm{hr}$ after the onset of infection. ( $C$ ) In vitro production of EPS by $S$. aureus Wood 46 incubated with $20 \%$ TCF for $1 \mathrm{hr}$; electron-dense material appears both around the cells and in the intercellular spaces (arrows). (D) $S$ aureus Wood 46 incubated for $3 \mathrm{hr}$ with TCF; EPS are strongly attached to the original cell wall (arrows) but not to the newly formed wall of the septa of dividing cells (arrowheads). Bars = $0.5 \mu \mathrm{m}$.
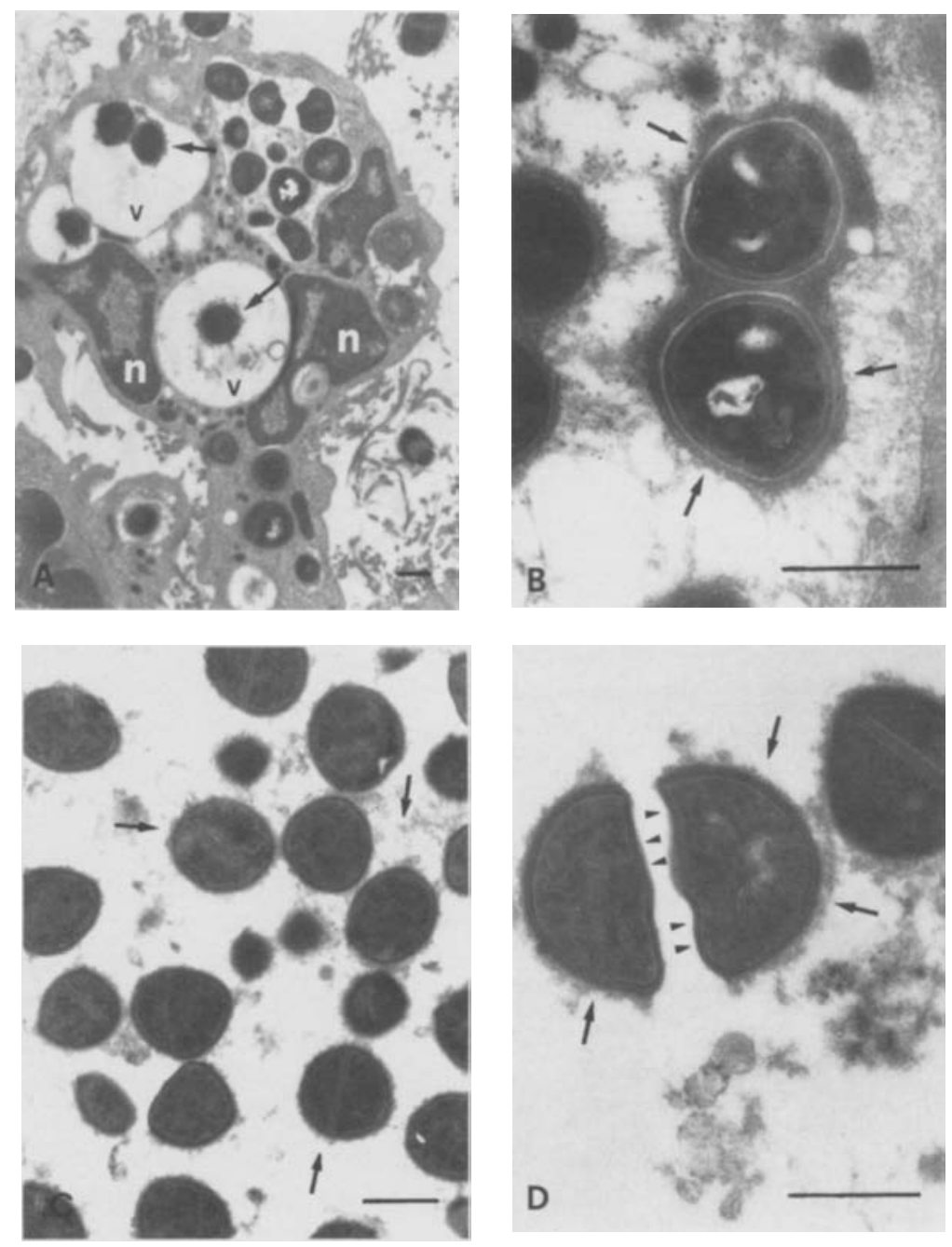
three hours (figure 2, B) after EPS-free $S$. aureus was inoculated into tissue cages, coated bacteria were uniformly present in TCF aspirated from infected animals. The EPS-rich bacteria were present as free forms in TCF or were located inside phagocytic vesicles of neutrophils (figure 2, A). Particularly condensed EPS together with the central bacterial nucleoid and the well-defined cell walls are shown in figure 2 , $B$.

To further define whether factors present in TCF contributed in a major way to production of EPS, we used an in vitro system in which $S$. aureus was incubated in $20 \%$ TCF in PBS, as indicated above. The initially EPS-free bacteria rapidly (i.e., after 1 $\mathrm{hr}$ and $3 \mathrm{hr}$ ) produced fresh EPS that were very similar to those observed in TCF from experimentally infected animals (figure 2, C and D). An interesting finding of these in vitro experiments was the nonuniform at tachment of EPS to the bacteria: in dividing cells (figure 2, D), EPS were attached to the original cell wall but not to the newly formed wall of the septa. This observation militates against the hypothesis that a surface coat may be passively adsorbed onto the bacteria from the surrounding medium. Light microscopy confirmed the presence of a true, trypsin-resistant capsule that excluded India ink particles. In contrast to incubation with TCF, in vitro incubation of $S$. aureus with human serum albumin did not lead to the production of EPS (data not shown). Thus we could produce bacteria that were either rich in EPS (by using TCF) or devoid of it (albumin).

Influence of EPS on the susceptibility of S. aureus to phagocytic ingestion. Before the phagocytic assay, bacteria were fixed with formaldehyde to prevent further production of EPS. Fixed, coated or uncoated cells were preopsonized for $15 \mathrm{~min}$ at $37 \mathrm{C}$ with either $10 \%$ serum or $20 \%$ TCF and then tested for uptake by neutrophils. The percentage of ingested $S$. aureus Wood 46 (figure 3 ) was higher for bacteria preopsonized with serum than for those preopsonized with TCF. EPS-rich and EPS-free S. aureus were ingested at the same rate when preopsonized with serum, but EPS-rich bacteria were ingested more rapidly $(P<.05)$ than EPS-free bacteria when both were preopsonized with TCF. Thus, the production of EPS did not inhibit - but in fact moderately increased - the uptake of $S$. aureus Wood 46 by the phagocytic cells. EPS-rich or EPS-free bacteria showed low, albeit measurable, uptake when in-

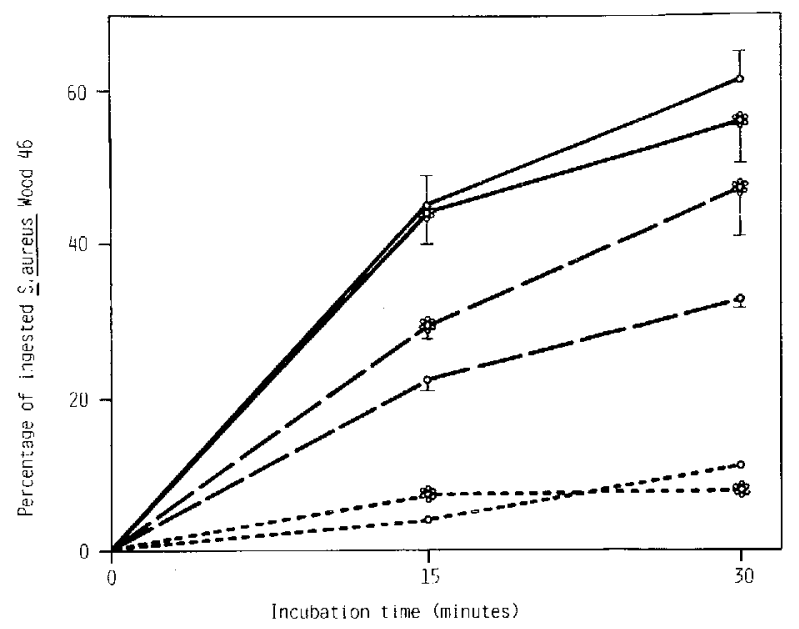

Figure 3. Phagocytic uptake of $S$. aureus Wood 46 incubated with $10^{\circ}$ peritoneal exudate neutrophils $/ \mathrm{ml}$. Fixed, radiolabeled EPS-free $(\mathrm{O}-\mathrm{O})$ or EPS-rich ( bacteria preopsonized for $15 \mathrm{~min}$ in $10 \%$ guinea pig serum are compared with fixed, radiolabeled, EPS-free $(\mathrm{O}-\mathrm{O})$ or EPS-rich ( — - bacteria preopsonized in 20\% TCF. Control incubations were run in $10 \%$ guinea pig serum and consisted of unopsonized, EPS-free ( $0--0)$ and EPS-rich ( ---- bacteria. Data are mean ( \pm SE) from three experiments.

cubated in either serum or TCF whose opsonic properties had been destroyed by heating (figure 3 ).

Influence of EPS on the adherence of $S$. aureus Wood 46 to fibronectin-coated coverslips. When live $S$. aureus were tested in the adherence assay, EPSrich bacteria preincubated in serum were $54 \%$ less adherent $(P<.01, n=6)$ to fibronectin-coated coverslips than were EPS-free $S$. aureus preincubated in albumin. In contrast, EPS-rich bacteria preincubated in TCF showed a slight, nonsignificant increase in adherence when compared with the EPSfree bacteria (figure 4, A). When EPS-rich or EPSfree $S$. aureus were fixed after preincubation (but before the adherence assay) with either TCF, serum, or albumin, the results were no different from those obtained with live bacteria (figure 4, B). As a final control experiment to insure that EPS were not directly involved in modifying adherence to fibronectin-coated coverslips, we fixed EPS-negative bacteria before incubating them with either TCF, serum, or albumin; the differences in adherence were the same as those shown in figure $4, \mathrm{~A}$ and $\mathrm{B}$ (figure $4, C)$. Thus, adsorbing components from either serum or TCF modified the adherence of $S$. aureus Wood 46, but did not affect the production of EPS. 


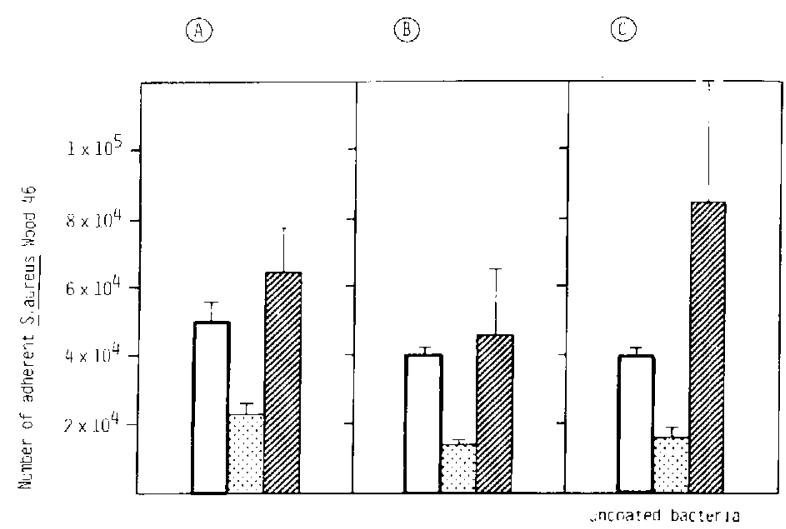

Figure 4. Adherence of $S$. aureus Wood 46 to fibronectin-coated polymethylmethacrylate coverslips. Radiolabeled bacteria were tested either $(A)$ under live conditions after incubation in either human serum albumin ( $\square$ ), serum ( $B$ ), or TCF (ZZ); or fixed with $0.5 \%$ formaldehyde overnight after $(B)$ or before $(C)$ preincubation in one of the three media. Data are mean ( $\pm \mathrm{SE})$ from six, three, and three experiments $(A, B, C$, respectively).

\section{Discussion}

This study documents EPS associated with S. aureus Wood 46 during growth in various media. The EPS was predominantly of a capsular type and, in some situations, was found in intercellular spaces as well. It was rapidly and abundantly produced in vivo during the onset of experimental foreign body infection. Such production could also be achieved by simple in vitro exposure of $S$. aureus to TCF. We also found that bacteria grown in the presence of albumin did not produce EPS, a result providing us with an important negative control. The role of these EPS in the adherence properties of $S$. aureus and in its susceptibility to opsonophagocytosis by neutrophils was tested and found to be negligible by a variety of techniques. Our results suggest that some humoral factors found in TCF are unrelated to the production of EPS and may increase the virulence of $S$. aureus Wood 46 in foreign body infections by enhancing both bacterial adherence and resistance to phagocytosis.

The relation between EPS, as described in our study, and materials referred to as "glycocalyx" or "slime" by other authors [6-16] is presently unclear, because no detailed chemical or antigenic composition of any of these materials is presently available. Even the distinction made on a morphological basis between capsular and intercellular exopolymers may disappear when their chemical composition is elucidated. Also, the biosynthesis of exopolymers must be defined to find some target-specific antibiotics.

We evaluated the role of EPS in modifying adherence to fibronectin and susceptibility to phagocytosis under a variety of experimental conditions and comparatively tested fixed and live bacteria. Formaldehyde-fixed bacterial cells have been repeatedly used to immunize animals against EPS [30, 31], with minimal changes in bacterial surface properties. The surprising result from both adherence and phagocytosis experiments performed with fixed and non-fixed bacteria was the absence of any significant role for EPS; EPS-rich and EPS-free $S$. aureus had almost identical properties in these assays. The exact mechanisms allowing EPS-rich and EPS-poor $S$. aureus Wood 46 to be opsonized properly and to interact with fibronectin are still unknown. We have previously reported that $S$. aureus Wood 46 was opsonized predominantly by the alternative pathway of complement activation [32]. The capsule of $S$. aureus has been reported to be highly permeable to macromolecules such as immunoglobulins or complement components $[33,34]$. These observations militate against the hypotheses that EPS may be a physical barrier between the bacterial and neutrophil receptors or between fibronectin and the putative fibronectin receptors of $S$. aureus Wood 46. Other strains of S. aureus, particularly the protein A-bearing clinical isolates, may behave differently from strain Wood 46.

Although our results and conclusions concerning the role of EPS in foreign body infections conflict with previous reports, which described the significant virulence of slime-producing bacteria in this clinical context [6-13], there were important methodological differences between previous observations and our experimental system. First, we used short periods of incubation (limited to a few hours) as opposed to one to several days [6-13]. Second, our sampling was limited to the fluid phase incubated with the foreign body, whereas most of the other observations concerned surface-adherent bacteria. Third, strain and species differences may be important in both the quantity and the chemical structure of EPS. This is particularly relevant for the strains of $S$. epidermidis, which were among the highest slime-producing gram-positive bacteria found in catheter-related sepsis [6-9]. Thus, our experimen- 
tal protocol does not exclude the possibility that in long-standing infections, EPS may contribute significantly to the persistence of the disease. However, we can state that EPS does not protect invading $S$. aureus bacteria, during the initial steps of foreign body infection, from recognition by neutrophils, nor does it influence bacterial adherence to fibronectin.

Finally, one aspect of our study concerns the role of TCF, a protein-rich inflammatory fluid in contact with the implanted foreign body [4], which decreased the susceptibility of $S$. aureus to phagocytic uptake by neutrophils (figure 4). This result may be linked with previous observations showing a progressive decrease in opsonic properties of TCF during experimental foreign body infection; these properties could be improved by incubating the bacteria with serum, either in vitro or in vivo [4]. Together, these results give further evidence that host defense mechanisms are altered in the vicinity of a foreign body and thus explain its high susceptibility to bacterial infections.

\section{References}

1. Hirshman HP, Schurman DJ. Deep infections following total hip replacement. In: Remington JS, Swartz MN, eds. Current clinical topics in infectious diseases. Vol. 3. New York: McGraw-Hill, 1982:206-17

2. Maki DG. Infections associated with intravascular lines. In: Remington JS, Swartz MN, eds. Current clinical topics in infectious diseases. Vol 3. New York: McGraw-Hill, 1982:309-63

3. Noble WC. The production of subcutaneous staphylococcal skin lesions in mice. Br J Exp Pathol 1965;46:254-62

4. Zimmerli W, Waldvogel FA, Vaudaux P, Nydegger UE. Pathogenesis of foreign body infection: description and characteristics of an animal model. J Infect Dis 1982;146:487-97

5. Zimmerli W, Lew PD, Waldvogel FA. Pathogenesis of foreign body infection. Evidence for a local granulocyte defect. J Clin Invest 1984;73:1191-200

6. Bayston R, Penny SR. Excessive production of mucoid substance in Staphylococcus SIIA: a possible factor in colonization of Holter shunts. Dev Med Child Neurol 1972; 14(Suppl 27):25-8

7. Christensen GD, Simpson WA, Bisno AL, Beachey EH. Adherence of slime-producing strains of Staphylococctus epidermidis to smooth surfaces. Infect Immun 1982; 37:318-26

8. Peters G, Locci R, Pulverer G. Microbial colonization of prosthetic devices. II. Scanning electron microscopy of naturally infected intravenous catheters. Zentralbl Bakteriol Mikrobiol Hyg [B] 1981;173:293-9

9. Peters G, Locci R, Pulverer G. Adherence and growth of coagulase-negative staphylococci on surfaces of intravenous catheters. J Infect Dis 1982;146:479-82
10. Gristina AG, Costerton JW. Bacterial adherence to biomaterials and tissue. J Bone Joint Surg [Br] 1985;67-A: 264-73

11. Costerton JW, Irvin RT, Cheng K-J. The bacterial glycocalyx in nature and disease. Annu Rev Microbiol 1981;35:299-324

12. Costerton JW, Irvin RT, Cheng K-J. The role of bacterial surface structures in pathogenesis. CRC Crit Rev Microbiol 1981;8:303-38

13. Marrie TJ, Nelligan J, Costerton JW. A scanning and transmission electron microscopic study of an infected endocardial pacemaker lead. Circulation 1982;66:1339-41

14. Schwarzmann S, Boring JR III. Antiphagocytic effect of slime from a mucoid strain of Pseudomonas aeruginosa. Infect Immun 1971;3:762-7

15. Nickel JC, Ruseska I, Wright JB, Costerton JW. Tobramycin resistance of Pseudomonas aeruginosa cells growing as a biofilm on urinary catheter material. Antimicrob Agents Chemother 1985;27:619-24

16. Sutherland IW. Bacterial exopolysaccharides - their nature and production. In: Sutherland I, ed. Surface carbohydrates of the prokaryotic cells. London: Academic Press, 1977:27-96

17. Geesey GG. Microbial exopolymers: ccological and economic considerations. ASM News 1982;48:9-14

18. Hawiger $\mathrm{J}$, Hammond DK, Timmons $\mathrm{S}$. Human fibrinogen possesses binding site for staphylococci on $A \alpha$ and $B \beta$ polypeptide chains. Nature 1975;258:643-5

19. Lopes JD, Dos Reis M, Brentani RR. Presence of laminin receptors in Staphylococcus aureus. Science 1985;229:275-7

20. Kuusela P. Fibronectin binds to Staphylococcus aureus. Nature 1978;276:718-20

21. Mosher DF, Proctor RA. Binding and factor $X 11 \mathrm{I}_{\mathrm{i}}$-mediated cross-linking of a 27-kilodalton fragment of fibronectin to Staphylococcus aureus. Science 1980;209:927-9

22. Vercellotti GM, Lussenhop D, Peterson PK, Furcht LT, McCarthy JB, Jacob HS, Moldow CF. Bacterial adherence to fibronectin and endothelial cells: a possible mechanism for bacterial tissue tropism. J Lab Clin Med 1984; 103:34-43

23. Vaudaux P, Suzuki R, Waldvogel FA, Morgenthaler JJ, Nydegger UE. Foreign body infection: role of fibronectin as a ligand for the adherence of Staphylococcus aureus. J Infect Dis 1984;150:546-53

24. Vaudaux PE, Waldvogel FA, Morgenthaler JJ, Nydegger UE. Adsorption of fibronectin onto polymethylmethacrylate and promotion of Staphylococcus aureus adherence. Infect Immun 1984;45:768-74

25. Kronvall G, Quic PG, Williams RC Jr. Quantitation of staphylococcal protein $\mathrm{A}$ : determination of equilibrium constant and number of protein A residues on bacteria. J Immunol 1970;104:273-8

26. Bayer ME, Thurow H. Polysaccharide capsule of Escherichia coli: microscope study of its size, structure, and sites of synthesis. J Bacteriol 1977;130:911-36

27. Reynolds ES. The use of lead citrate at high $\mathrm{pH}$ as an electronopaque stain in electron microscopy. J Cell Biol 1963; 17:208-12

28. Tan JS, Watanakunakorn C, Phair JP. A modified assay of neutrophil function: use of lysostaphin to differentiate 
defective phagocytosis from impaired intracellular killing. J Lab Clin Med 1971;78:316-22

29. Vaudaux $P$, Waldvogel FA. Gentamicin antibacterial activ ity in the presence of human polymorphonuclear leukocytes. Antimicrob Agents Chemother 1979;16:743-9

30. Brock $\mathbf{J H}$, Reiter B. Chemical and biological properties of extracellular slime produced by Staphylococcus aureus grown in high-carbohydrate, high-salt medium. Infect Immun 1976;13:653-60

31. Caputy GG, Costerton JW. Morphological examination of the glycocalyces of Staphylococcus aureus strains Wiley and Smith. Infect Immun 1982;36:759-67

32. Lew PD, Zubler R, Vaudaux P, Farquet JJ, Waldvogel FA,
Lambert P-H. Decreased heat-labile opsonic activity and complement levels associated with evidence of $\mathrm{C} 3$ breakdown products in infected pleural effusions. J Clin Invest 1979;63:326-34

33. Wilkinson BJ, Sisson SP, Kim Y, Peterson PK. Localization of the third component of complement on the cell wall of encapsulated Staphylococcus aureus M: implications for the mechanism of resistance to phagocytosis. Infect Immun 1979;26:1159-63

34. King BF, Wilkinson BJ. Binding of human immunoglobulin G to protein A in encapsulated Staphylococcus aureus. Infect Immun 1981;33:666-72 